\title{
Factors Influencing Community Involvement Among BSEd - Social Studies Students
}

\author{
MYRNA C. VILLAROJO \\ mcvillarojo66@gmail.com \\ http://orcid.org/0000-0003-1729-073X \\ JIGS S. SEÑAGAN \\ salaumjigs@gmail.com \\ http://orcid.org/0000-0002-5866-3726 \\ RINADEL MONICA C. PLAZA \\ chantiacomonica@yahoo.com \\ http://orcid.org/0000-0002-4392-0291 \\ GEMEMA M. DANO \\ gemema020@gmail.com \\ http://orcid.org/0000-0001-7017-512X \\ FILOMENO J. MAGDUA \\ filmagdua12@gmail.com \\ http://orcid.org/0000-0002-8310-8097 \\ JESSA VIL C. QUIDET \\ Qjessavil_@yahoo.com \\ http://orcid.org/0000-0001-9563-2841

\section{AILEEN T. ANUNCIADO} \\ ailyn_anunciado@yahoo.com \\ http://orcid.org/0000-0002-8778-544X
}




\author{
BERNARD M. LUEGA \\ assasinbeergo@gmail.com \\ http://orcid.org/0000-0002-5423-5652
}

\begin{abstract}
Community involvement is the engagement and participation of an individual who renders service for community development and selfimprovement. For students, this concept is part of the basic and collegiate curriculum as service learning, which links content standards to reallife learning by self-reflection. The study focused on factors influencing community involvement among BSED-Social Studies students of the University of Bohol during the first semester of the academic year 20182019, basing on Bronfenbrenner's Socio-ecological Theory. The study utilized a quantitative method through a self-constructed tool and was then processed through percentage, weighted mean, composite mean, Chisquare, Analysis of Variance, and Scheffe's test. The study revealed that respondents strongly agreed that individual factors had influenced them all the time. The result showed a significant relationship between community involvement and the individual factors.
\end{abstract}

Keywords: Social Science, community involvement, community engagement, quantitative method, Chi-square, Analysis of Variance, and Scheffe's test, Philippines

\title{
INTRODUCTION
}

Community involvement, the participation, and engagement of every member in the community with a consensus to achieve a common goal is a relevant concept that can be classified in various perspectives (Barasa \& Jelagat, 2013). It is the people's involvement in activities that requires the interrelationship of efforts and culture that are often cited in a specific geographical location (Greer, 2017). Particular problems arise in the community such as political, environmental, health and socio-cultural problems that create effective intervention strategies (Maleki, Hosseinpour, Rafiemanesh, Salehi, Lotfi, Naserizadeh, Yari, Koohi, Holakouie Naieni, 
2014) formed and organized by community members that lead to community participation, volunteerism, and involvement.

Both the community and the volunteers benefit in community involvement. These engagements include the benefits of personal growth, social interaction recognition, responsibility, and advancement (Llenares and Deocaris, 2015). There are also important determinants for potential and actual volunteers, such as altruism, frequent contact with friends, health, and religious values (Dury, De Donder, De Witte, Buffel, Jacquet, and Verte, 2015). It is also suggested that the non-profit voluntary group shows more interest in promoting policies that would increase educational opportunities and would foster civic engagement, religious participation, and social interaction (Forbes and Zampelli, 2014).

The study utilized Bronfenbrenner's Socio-ecological Theory, which was discussed in the book "The Ecology of Human Development by Bronfenbrenner (1979) as its theoretical underpinning. The socio-ecological model explains that the person is first seen as a growing, dynamic entity. Second, the environment exerts its influence, and third, the environment is not limited to external influences from the more massive surrounding structure, namely microsystem, mesosystem, exosystem, and macrosystems. It also suggests that community involvement is affected by multiple levels of influence - individual, interpersonal, organizational, community, and public policy. The theory, therefore, highlights the various levels of interaction that influence each other in a continuous process of change as an attempt to understand the complexity of individual functioning (Naidoo, Duncan, Roos, and Bowman, 2007).

Further, the same theory says that human development is shaped through the interaction between the individual and his/her environment. Thus, social human is greatly influenced by the smallest internal Factor to the broadest external factors. Those factors mold and nurture the behavior of the social aspects of human being of how he/she interacts to the status quo of his/her existence.

Experiential learning, as advocated by Kolb (2014) explains the direct sense of experience and in-context action as the primary source of learning. Lave and Wenger's (1991) Situated learning theory suggests that learning is unintentional; people likely learn more in active participation and situated within authentic activity, context, and culture. It relates that knowledge can be attained through placing an individual in a natural environment which develops his/her social dimension. Further, the Motivation Theory 
by Maslow (1943) implies that highly motivated students enjoy learning and participating more than those who are not motivated. Even when things turn out to be difficult, they persist and persevere that result in satisfactory performance. Also, Bandura's Social Learning Theory (1977) that discussed complex behaviors, such as solving problems and coping with the real world are the results of competent models' exposure who shows the behavior appropriately.

The Social Capital concept as defined by Coleman (1988) focuses on the individual use while Bourdieu (1983) on the use of social capital by particular social groups and Putnam (2000) on social capital, while Lin (2001) also emphasizes the use of social capital in the business or search for jobs and social status. All the main theoretical contributions of Bourdieu, Coleman, Putnam, and Lin agree that social capital is embedded in social relationships, but they differ as to their perspectives on the use of social capital to community involvement.

In the book by Mayo and Craig (1995) entitled "Community Empowerment: A Reader in Participation and Development," community involvement is an essential part of self-help and process empowerment. People who were involved gain self-esteem, knowledge, and develop new skills. The book of Epstein (2018) states that family, school, and community partnerships share responsibility for students' learning and development. Furthermore, service-learning as mentioned in the article by Sanders (2003) provides students with opportunities to assist individuals or agencies in addressing social and environmental problems or community needs which these experiences include working emotionally to physically disabled children, planting community gardens, helping with infant care in the hospital.

Social capital also plays a vital role in community empowerment. With the non-governmental organizations' initiatives, it is considered as a 'grassroots' process by which community becomes responsible' organize and plan together; develop healthy options; empower themselves; reduce ignorance, poverty and suffering; create employment and economic opportunities; achieve social, economic, cultural and environmental goals (Islam, 2016). It was considered that central government could play a crucial role in shaping community involvement, through policies influenced by contrasting ideological conceptions of citizenship and political expediency, as long as they use methods and processes that meet evaluation criteria that are essential for active public participation: acceptance criteria, which 
concern features of a way making it acceptable to the broader public, and process criteria, which concern features liable to ensure that it happens in an effective manner (Marinetto, 2003; Rowe and Frewer, 2000).

The study of DeVito (2016) states that there are features found as significant influence of student's eagerness to participate in activities and these include communication, collaboration, active involvement in activities, interactions between students and teachers, academic challenges and supporting classroom and family environment. Waweru (2015) found out that the key factors that lead to community participation are benefits, self-growth on interest, developmental need, previous development involvements, the sense of belongingness, and community service. Muro and Namusonge (2015) investigate the Governmental Factor affecting community participation in public development and the factors that shape participation. It was found out that people participate in public development projects through financial, material, and labor contribution, and it was also showed that enjoying the benefits of community participation accrued from the projects.

Sahay (2015) concluded that women have a significant role in community participation in environmental management. While in a study by Sulaiman, Othman, Samah, Yero, D'Silva, and Ortega (2014), it was determined that four factors influence community participation based on the socio-ecological model and these are Individual, Community, Organizational and Governmental Factors. The study concluded that these factors do contribute a lot a positive outlook and effect in community participation.

Preston (2013) found that participants' response affirmed that participation of the school in the community improved the relationships of teachers and community members. Further, the study produced data that the proximity of the community outside the school negatively affects the social relations of the people involved. While the study of Ye Zhang (2010) found that residents' preferences about community involvement in tourism encompass spontaneous participation, such was influenced by their perceived economic benefits, knowledge about tourism, attitude towards the job and environmental sustainability. It was also found that more males preferred spontaneous participation than females. Hee Chee (2006) studied community involvement in the context of population aging, found that the rational choice of individual community involvement is based on the expectation of personal benefits. 
This particular study pursued the following objectives:

1. To describe the profile of the Social Studies significant students;

2. To determine the level of agreement in terms of influence among students' involvement in the community;

3. To relate the profile of the respondents and the factors that influence community involvement; and,

4. To determine if there is a significant degree of variance among all the factors that influence community involvement.

\section{METHODOLOGY}

The study utilized a quantitative method with the use of a selfconstructed survey instrument that was distributed to 68 studentrespondents among the BSED - Social Studies students of the University of Bohol for the first semester of the academic year 2018-2019.

The study underwent the scrutiny of the Research Ethics Committee of the University, and it passed the ethical standards.

\section{RESULTS AND DISCUSSION}

Majority of the respondents $(66.18 \%)$ were $18-20$ years of age; second in rank were $21-23$ years old (16.18\%); third in rank were slightly above a tenth (11.76\%) and they were $24-26$ years old, and a very few $(5.88 \%)$ were 27 years and above. Almost three-fourths $(72.06 \%$ were females, and the remaining percentage (27.94\%) were males.

Individual Factor that influenced Community Involvement all the time yielded a composite mean of 3.38. The top rank item was "I believe that participating in the community programs strengthen my profile in job application forms and resumes." This finding is supported by the study of Waweru (2001) where she found out the critical factors to community participation, include benefits, self-growth, developmental needs; previous developmental involvement and sense of belongingness, those items are in line to individual factors in this study.

Interpersonal Factor had a composite mean of 2.92 which means that these factors had influenced them most of the time. This result agrees with the study of Preston (2013) that community involvement in school is influenced by social relationship generated from educators, 
parents, and community members. It is also supported in the book published by Epstein (2018) that people at home, in school and the community work together to improve schools and increase the success of all students.

Institutional Factor garnered a composite mean of 3.16, which implies that such Factor has influenced their Community Involvement most of the time. Findings in the study of Mattis, Jagers, Hatcher, Lawhon, Murphy, \& Murray, (2000) revealed that social capital, communalism, and religiosity are the predictors of volunteerism. Further, there is a higher possibility to engage more in volunteer work as one joins a community-based organization. Furthermore, the study of DeVito (2016) found that a more significant influence of student eagerness to participate includes communication, collaboration, active involvement in activities, and interaction among teachers, the academic challenge, and supporting classroom.

Societal Factor garnered a composite mean of 3.20 upon which the respondents perceived that influenced their Community Involvement most of the time. This finding is related to the result of Sahay (2015), which states that the success of any program requires the participation of various stakeholders. The role of the local community with a specific focus on women in managing environmental program is through sustainable use of natural resources and of disposing and keeping the generated wastes judiciously. There is a congruence of this current results with that of the writeup of Islam (2016). That study stressed that the increasing grassroots' processes in community involvement had several advantages. These advantages include empowering themselves, creates employment and economic opportunities, achieve social, economic, rural and environmental goals.

Table 1. Summary on Level of Agreement in terms of Influence among Respondents' Involvement in the Community

Factors

Weighted Mean

Interpretation

Rank

Individual

Interpersonal

Institutional
3.38

2.92

3.16
Influential all the time

Influential most of the time

Influential most of the time
4 


\begin{tabular}{cccc}
\hline Factors & Weighted Mean & Interpretation & Rank \\
\hline Societal & 3.2 & Influential most of the time & 3 \\
Governmental & 3.28 & Influential all the time & 2 \\
$\begin{array}{c}\text { Overall } \\
\text { Composite } \\
\text { Mean }\end{array}$ & 3.19 & Influential most of the time \\
\hline
\end{tabular}

Legend:

3.25-4.0 Influential all the time

2.50-3.24 Influential most of the time

1.75-2.49 Influential sometimes

1.0-1.74 No influence at all

Table 1 reveals that overall, the respondents were influenced most of the time by all the factors in the involvement of the community. The Individual Factor had the highest composite mean of 3.38, followed by the Governmental (3.28), Societal (3.20), Institutional (3.16) and Interpersonal (2.92) factors.

Table 2. Testing the Significant Relationship between Sex and Level of Agreement of Factors that Influence Community Involvement

\begin{tabular}{cccc}
\hline & $\mathbf{N}=68$ & & \\
\hline Sex & Male & Female & Total \\
\hline Strongly Agree & 8 & 26 & 34 \\
Moderately Agree & 6 & 20 & 26 \\
Slightly Agree & 5 & 3 & 8 \\
Disagree & 0 & 0 & 0 \\
Total & 19 & 49 & \\
& $=5.380$ & \\
& Critical Value of at 2df (0.05) $=3.840$ & \\
& Result: SIGNIFICANT & \\
Ho: Rejected &
\end{tabular}

Table 2 shows that there is significant relationship between the sex and the factor on Community Involvement. The computed was 5.380 higher 
than the tabular value of 3.840 at $2 \mathrm{df}$ alpha level 0.05 level of significance, hence, the result is significant. The null hypothesis is rejected.

As to the Analysis of Variance Among all the Factors that Influence Community Involvement, the obtained computed f-value of 5.2976 was higher than the critical value of 2.580 at 4 by $45 \mathrm{df}$ and 0.05 level of significance; thus, the null hypothesis is rejected. The result showed that there is a significant degree of variance among all the factors.

Table 3. ANOVA Table of the Difference of Community Involvement with Groups by Factor

\begin{tabular}{cccccr}
\hline $\begin{array}{c}\text { Sources of } \\
\text { Variation }\end{array}$ & Df & $\begin{array}{c}\text { Sum of } \\
\text { Squares }\end{array}$ & Mean Squares & \multicolumn{2}{c}{ F- Value } \\
\hline Between Groups & 3 & 1.1854 & 0.29635 & $\mathbf{5 . 2 9 7 6}$ & $\mathbf{2 . 5 8 0}$ \\
Within Groups & 45 & 2.5174 & 0.05594 & \multicolumn{2}{c}{ Result: Significant } \\
Total & 48 & 3.7028 & & \multicolumn{2}{c}{ Ho: Rejected } \\
\hline
\end{tabular}

The result shows significant pairings between individual and interpersonal, interpersonal and organizational, interpersonal and community, interpersonal and governmental factors and it also shows insignificant pairing between Individual and Organizational, Individual and Community, Individual and Governmental, Organizational and Community, Organizational and Governmental, Community and Governmental.

Table 4. Signified Paired Contrasts Using Scheffe's Test

\begin{tabular}{lcccccccc}
\hline \multicolumn{1}{c}{ Between } & Mean 1 & Mean 2 & $\mathrm{D}$ & $\mathrm{N} 1$ & $\mathrm{~N} 2$ & $\mathrm{~F}^{\prime}$ & $\mathrm{F}^{*} \mathrm{k}-1$ & Interpretation \\
\hline $\begin{array}{l}\text { Individual VS } \\
\text { Interpersonal }\end{array}$ & 3.38 & 2.92 & 0.46 & 10 & 10 & 18.91312 & 4.819 & Significant \\
$\begin{array}{l}\text { Individual VS } \\
\text { Organizational } \\
\text { Individual VS }\end{array}$ & 3.38 & 3.16 & 0.22 & 10 & 10 & 4.326064 & 4.819 & Insignificant \\
$\begin{array}{l}\text { Community } \\
\text { Individual VS }\end{array}$ & 3.38 & 3.20 & 0.18 & 10 & 10 & 2.89596 & 4.819 & Insignificant \\
$\begin{array}{l}\text { Governmental } \\
\text { Interpersonal VS }\end{array}$ & 3.38 & 3.28 & 0.1 & 10 & 10 & 0.893815 & 4.819 & Insignificant \\
$\begin{array}{l}\text { Organizational } \\
\text { Interpersonal VS }\end{array}$ & 2.92 & 3.16 & -0.24 & 10 & 10 & 5.148373 & 4.819 & Significant \\
$\begin{array}{l}\text { Community } \\
\text { Interpersonal VS }\end{array}$ & 2.92 & 3.28 & -0.36 & 10 & 10 & 11.58384 & 4.819 & Significant \\
$\begin{array}{l}\text { Governmental } \\
\text { Organizational } \\
\text { VS Community }\end{array}$ & 3.16 & 3.20 & -0.04 & 10 & 10 & 0.14301 & 4.819 & Insignificant \\
\hline
\end{tabular}




\begin{tabular}{lcccccccc}
\hline \multicolumn{1}{c}{ Between } & Mean 1 & Mean 2 & $\mathrm{D}$ & $\mathrm{N} 1$ & $\mathrm{~N} 2$ & $\mathrm{~F}^{\prime}$ & $\mathrm{F}^{*} \mathrm{k}-1$ & Interpretation \\
\hline $\begin{array}{l}\text { Organizational } \\
\text { VS Governmental }\end{array}$ & 3.16 & 3.28 & -0.12 & 10 & 10 & 1.287093 & 4.819 & Insignificant \\
$\begin{array}{l}\text { Community VS } \\
\text { Governmental }\end{array}$ & 3.20 & 3.28 & -0.08 & 10 & 10 & 0.572041 & 4.819 & Insignificant \\
\hline
\end{tabular}

As to the overall variance of the six groups, the result was significant. It showed that Individual (3.38) and Governmental (3.28) factors influenced them all the time to community involvement.

The respondents perceived Interpersonal, Institutional, and Societal factors influenced them most of the time to Community Involvement with composite mean of $2.92,3.16$, and 3.20 , respectively.

Based on the result, Interpersonal Factor created the variance among the different factors influencing Community Involvement.

\section{CONCLUSIONS}

Based on the findings, Individual factors have influenced the respondents all the time in community involvement; while Interpersonal, Institutional, and Societal Factors have influenced the respondents most of the time.

There was a significant relationship between sex and the factors that influence Community Involvement, which shows that the sex of the respondents' matters in the influence on Community Involvement. There was a significant degree of variance among all the influencing factors to community involvement, which shows that the respondents have been influenced variously by each identified factor.

As to the overall variance of the factors, the result was significant. It also shows that Individual and Government factors were perceived by the respondents as influencers of their Community Involvement all the time. Further, Interpersonal, Institutional, and Societal factors were believed by the respondents as an influencer of their Community Involvement most of the time.

\section{RECOMMENDATIONS}

1. A need for programs in the academe to instill the sense of volunteerism of students in the community projects and involvement in the civil society's advocacies. 
2. Action plans such as school-parent, community-based programs can be proposed by the academe that can reinforce and further improve interpersonal relationships of the students to their teachers, classmates, families, friends, and relatives while empowering them to their respective localities.

3. Linkages to Government agencies and Non-Government Organizations shall be initiated by the academe to involve teaching/ non-teaching employees and students to spearhead advocacies and programs as it will allow them to interact with others, and more importantly, build the spirit of social responsibility.

4. For further research, another study on influencing factors and level of Community Involvement must be studied to determine if the influencing factors reinforced the respondents to be involved in the community.

\section{REFERENCES CITED}

Bandura, A. (1977). Social learning theory. Englewood Cliffs, NJ: Prentice Hall. Retrieved from http://bit.ly/2Seh7xx, (accessed last 15 March 2018).

Barasa, F., \& Jelagat, T. (2013). Community participation in project planning, management and implementation: building the foundation for sustainable development. International Journal of Current Research, 5(02), 398-40. Retrieved from http://bit.ly/2GstuTJ, (accessed last 18 August 2018).

Bourdieu P., (1983) Handbook of Theory and Research for the Sociology of Education, (Forms of Capital' in J. Richardsons (ed.)), Greenwood, New York. Retrieved from http://bit.ly/2XrlY1d, (accessed last 18 July 2018)

Bronfenbrenner, U. (1979). Ecology of Human Development: Experiments by Nature and Design. Cambridge: Harvard University Press. Retrieved from http://bit.ly/2FHOfOA, (accessed last 18 July 2018).

Coleman, J. S. (1988). Social capital in the creation of human capital. American journal of sociology, 94, S95-S120. Retrieved from https://bit. ly/2kboqef, (accessed last 18 July 2018). 
Greer, S. (2017). The concept of community: Readings with interpretations. Routledge. Retrieved from http://bit.ly/2DjU2Vf, (accessed last 18 July 2018).

DeVito, M. (2016). Factors Influencing Student Engagement. Unpublished Certificate of Advanced Study Thesis, Sacred Heart University, Fairfield, CT. Retrieved from http://bit.ly/2QswuVM, (accessed last 15 August 2018).

Dury, S., De Donder, L., De Witte, N., Buffel, T., Jacquet, W., \& Verté, D. (2015). To volunteer or not: The influence of individual characteristics, resources, and social factors on the likelihood of volunteering by older adults. Nonprofit and Voluntary Sector Quarterly, 44(6), 1107-1128. Retrieved from http://bit.ly/2ShNUSt, (accessed last 15 August 2018).

Epstein, J. L. (2018). School, family, and community partnerships: Your handbook for action. Thousand Oaks, CA: Corwin, A SAGE Company. Retrieved from http://bit.ly/2FNmTF1, (accessed last 13 August 2018).

Forbes, K. F., \& Zampelli, E. M. (2014). Volunteerism: The influences of social, religious, and human capital. Nonprofit and Voluntary Sector Quarterly, 43(2), 227-253. Retrieved from http://bit.ly/2RkA95e, (accessed last 15 August 2018).

Hee Chee, K. (2006). Community mobilization in the context of population aging. Sociological Spectrum, 26(1), 43-61. Retrieved from https://bit. ly/2QlgXgK, (accessed last 15 August 2018).

Islam, M. (2016). NGOs, Social Capital and Community Empowerment in Bangladesh. Singapore, Singapore: Springer Nature. Retrieved from http://bit.ly/2zvwv1F, (accessed last 15 August 2018).

Kolb, D. A. (2014). Experiential Learning: Experience as the Source of Learning and Development. Retrieved March 19, 2018, from https:// goo.gl/TrLWtC, (accessed last 4 March 2018)

Lave, J., \& Wenger, E. (1991). Situated Learning: Legitimate Peripheral Participation. 1-24. Retrieved from https://goo.gl/GERt4w, (accessed last 15 July 15 2018). 
Lin N., Social Capital. A Theory of Social Structure and Action, Cambridge University Press, Cambridge 2001. Retrieved from http://bit.ly/2XrlY1d, (accessed last 25 March 2018).

Llenares, I. \& Deocaris, C. (2015). Motivations for Volunteerism Among Filipino College Students. International Journal of Education and Research. 3. 599-610. Retrieved from https://bit.ly/2PEwbCV , (accessed last 18 August 2018).

Maleki, F., Hosseinpour, M., Rafiemanesh, H., Salehi, F., Lotfi, Z., Naserizadeh, M. R., \& Holakouie Naieni, K. (2014). The review of community assessment papers to determine priority problems in selected populations of Iran. Journal of School of Public Health \& Institute of Public Health Research, 12(3). Retrieved from http://bit. ly/2E2DI2F, (accessed last 5 August 2018).

Marinetto, M. (2003). Who wants to be an active citizen? The politics and practice of community involvement. Sociology, 37(1), 103-120. Retrieved from https://bit.ly/2AH4VyU, (accessed 1 July 2018).

Maslow, A. H. (1943). Preface to Motivation Theory. APA Psycnet, 85-92. Retrieved from https://goo.gl/fswUuP, (accessed last 22 August 2018).

Mattis, J. S., Jagers, R. J., Hatcher, C. A., Lawhon, G. D., Murphy, E. J., \& Murray, Y. F. (2000). Religiosity, volunteerism, and community involvement among African American men: An exploratory analysis. Journal of community Psychology, 28(4), 391-406. Retrieved from http://bit.ly/2Rew3vz, (accessed last 15 August 2018).

Mayo, M., \& Craig, G. (1995). Community empowerment: A reader in participation and development. London: Zed Books. Retrieved from http://bit.ly/2FKWpUI, (accessed last 15 July 2018).

Muro, J. E., \& Namusonge, G. S. (2015). Governance Factors Affecting Community Participation In Public Development Projects In Meru District In Arusha In Tanzania. International Journal of Scientific and Technology Research, 4(06). Retrieved from http://bit.ly/2E1OLDw, (accessed last 15 July 2018). 
Naidoo, A., Duncan, N., Roos, V., Pillay, J., \& Bowman, B. (2007). Analysis, context and action: An introduction to community psychology. Community psychology in South Africa: Theory, context and practice, 9-23. Retrieved from http://bit.ly/2BBkzwQ, (accessed last 15 July 2018).

Preston, J. P. (2013). Community Involvement in School: Social Relationships in a Bedroom Community. Canadian Journal of Education, 36(3), 413437. Retrieved from http://bit.ly/2E005jB, (accessed last 14 August 2018).

Putnam RD. (2000). Bowling Alone: the Collapse and Revival of American Community. New York: Simon \& Schuster. Retrieved from http://bit. ly/2KC8x9i, (accessed last 15 August 2018).

Rowe, G., \& Frewer, L. J. (2000). Public participation methods: a framework for evaluation. Science, technology, \& human values, 25(1), 3-29. Retrieved from https://bit.ly/2AFOYJu, (accessed last 15 July 2018).

Sahay, R. (2015). Community Participation In Environmental Management: Role Of Women. 1-9. Retrieved J from http://bit.ly/2Pdms6n, (accessed last 15 August 2018).

Sanders, Mavis. (2003). Community Involvement In SchoolsFrom Concept to Practice. Education and Urban Society - EDUC URBAN SOC. 35. 161-180. 10.1177/0013124502239390. Retrieved from http://bit. ly/2RjUwPZ, (accessed last 4 August 2018).

Sulaiman, A. H., Othman, J., Samah, B. A., Yero, A., D'Silva, J. L., \& Ortega, A. (2014). Determinants of community participation in community policing program in Malaysia. Journal of Applied Sciences, 14(20), 2439-2449. Retrieved from http://bit.ly/2E1afki, (accessed last 15 July 2018).

Waweru, R. (2015). Factors Which Promote Community Participation in the Community Driven Development Approach. International Journal of Humanities \& Social Science Studies, 2349, 6959. Retrieved from http://bit.ly/2znFkur, (accessed last 15 August 2018). 
Zhang, Y. (2010). Personal factors that influence residents' preferences about community involvement in tourism planning (Doctoral dissertation). Retrieved from http://bit.ly/2PXSDMd, (accessed last 15 August 2018). 